\title{
Arı Ürünlerinin (Bal, Propolis) Leishmania tropica Promastigotları Üzerine Antileyşmanyal Etkilerinin Araştırılması
}

\author{
Investigation of Anti-leishmanial Effects of Bee Products \\ (Honey, Propolis) on Leishmania tropica Promastigotes
}

\author{
Tülay $\operatorname{AKSOY}^{1}($ ID), Eda SiVCAN²(ID), Fatma DOĞAN²(ID), Songül ÇETiN²(ID), \\ Türkan Mutlu YAR ${ }^{1}$ (ID) \\ 1 İnönü Üniversitesi Tıp Fakültesi, Tıbbi Parazitoloji Anabilim Dalı, Malatya. \\ ${ }^{1}$ Inonü University Faculty of Medicine, Department of Medical Parasitology, Malatya, Turkey. \\ 2 Erciyes Üniversitesi Tıp Fakültesi, Tıbbi Parazitoloji Anabilim Dalı, Kayseri. \\ 2 Erciyes University Faculty of Medicine, Department of Medical Parasitology, Kayseri, Turkey.
}

Makale Atıfı: Aksoy T, Sivcan E, Doğan F, Çetin S, Yar TM. Arı ürünlerinin (bal, propolis) Leishmania tropica promastigotları üzerine antileyşmanyal etkilerinin araştırılması. Mikrobiyol Bul 2020;54(3):479-489.

\section{ÖZ}

Bu çalışma, kutanöz leyşmanyazis etkeni Leishmania tropica promastigotları kullanılarak arı ürünlerinin (bal, propolis) antileyşmanyal etkilerinin in vitro kültür ortamında araştııılması amacıyla yapılmıştır. Çalışmada kullanılan bal (çam, çiçek ve kestane) ve propolisin in vitro antileyşmanyal etkinliği mikrodilüsyon yöntemi kullanılarak değerlendirilmiştir. Arı ürünlerinden olan bal \%10 "fetal calf serum (FCS)" içeren RPMI besiyeri ile çözdürülmüş ve aynı besiyeri içerisinde sulandırılmış olup, $62.5-1000 \mathrm{mg} / \mathrm{ml}$ arasındaki konsantrasyonlarda seri dilüsyonları hazırlanmıştır. Propolis ise etil alkol ile çözdürülmüş, hazırlanmış olan bu konsantrasyonlarda alkol oranının $\% 50$ 'den fazla olmasından ve bu oranın parazit gelişimini olumsuz etkileyeceğini düşündüğümüzden dolayı, tüm bu konsantrasyonlardan yalnız $2.5 \mu$ l kullanılarak \%10 FCS içeren RPMI besiyeri içerisinde sulandırımış ve ardından 50-800 $\mu \mathrm{g} / \mathrm{ml}$ arasındaki konsantrasyonlarda seri dilüsyonları hazırlanmıştır. Hazırlanan dilüsyonların üzerine, kuyucuklardaki son konsantrasyonları 1 $\times 10^{6}$ promastigot $/ \mathrm{ml}$ olacak şekilde promastigot süspansiyonu ilave edilmiş ardından $26^{\circ} \mathrm{C}^{\prime}$ lik etüvde 24 ve 48 saat inkübe edilmiştir. İnkübasyondan sonra promastigotlar morfoloji, hareketlilik ve canlı parazit yoğunluğu yönünden mikroskobik olarak, hücre canlıı̆̆ı ise MTS yöntemi ile incelenerek \%50 inhibitör konsantrasyonları $\left(\mathrm{IC}_{50}\right)$ kontrol grupları ile karşılaştırılarak belirlenmiştir. Propolisin (50, 100, 200, 400 ve $800 \mu \mathrm{g} / \mathrm{ml})$ ve balların $(62.5,125,250,500 \mathrm{ve} 1000 \mathrm{mg} / \mathrm{ml})$ beş farklı konsantrasyonu promastigotlar üzerine antileyşmanyal aktivitesi in vitro ortamda değerlendirilmiş ve mikroskobik incelemelerde çam balının $62.5 \mathrm{mg} / \mathrm{ml}$, çiçek balının $250 \mathrm{mg} / \mathrm{ml}$, kestane balının ise $125 \mathrm{mg} / \mathrm{ml}$ konsantrasyonlarından itibaren antileyşmanyal etkinlik gösterdiği, çam balının promastigotlar üzerine daha etkin olduğu $(p<0.05)$, propolisin ise $100 \mu \mathrm{g} / \mathrm{ml}$ konsantrasyonundan itibaren etki ettiği gözlemlenmiş̧ir. Propolisin çok düşük konsantrasyonlarının özellikle parazitlerin morfolojik yapılarında değişmelere sebep olduğu ve bu konuda diğer arı ürünlerinden daha etkin olduğu belirlenmiştir. L.tropica promastigot hücre kültürü üzerine uygulanan çam balı $\left(I C_{50}=109.28 \mathrm{mg} / \mathrm{ml}\right)$, çiçek balı $\left(I_{50}=248.07 \mathrm{mg} / \mathrm{ml}\right)$, kestane balı $\left(\mathrm{IC}_{50}=147.65\right.$ $\mathrm{mg} / \mathrm{ml})$ ve propolisin $\left(\mathrm{IC}_{50}=82.98 \mu \mathrm{g} / \mathrm{ml}\right)$ hücre çoğalmasını engellediği $(\mathrm{p}<0.05)$ ve $I C_{50}$ değerlerinin 
zamana bağlı olarak azaldığı MTS yöntemiyle tespit edilmiştir. Yapılan bu çalışmada çam balı, çiçek balı, kestane balı ve propolisin çeşitli konsantrasyonlarının L.tropica promastigotları üzerine antileyşmanyal etkinlik gösterdiği tespit edilmiş, bunlardan çam balının 48 saatlik inkübasyon süresi sonunda promastigotlar üzerinde daha etkin olduğu, propolisin ise çok düşük konsantrasyonlarında dahi parazitlerin hem morfolojisinde hem de hücre inhibisyonunda daha etkili olduğu gözlemlenmiştir. Elde edilen bu veriler doğrultusunda arı ürünlerinin kutanöz leyşmanyazis enfeksiyonlarına karşı alternatif bir tedavi yöntemi olarak kullanılabileceği ve ileri çalısmaların yapılması gerektiği kanısına varılmıstır.

Anahtar kelimeler: Leishmania tropica; bal; propolis; antileyşmanyal etki

\section{ABSTRACT}

This study was aimed to investigate the anti-leishmanial effects of bee products (honey and propolis) by using the causative agent of cutaneous leishmaniasis Leishmania tropica promastigotes, in in vitro culture. In vitro anti-leishmanial efficacy of honey (pine, flower and chestnut) and propolis used in the study were evaluated using the microdilution method. Honey, which is a bee product, was dissolved with RPMI medium containing fetal calf serum (FCS) and diluted in the same medium, and serial dilutions were prepared in concentrations between $62.5-1000 \mathrm{mg} / \mathrm{ml}$. Propolis, on the other hand, was dissolved with ethyl alcohol and only $2.5 \mu \mathrm{l}$ was used from all these concentrations since the alcohol content was more than $50 \%$ in these concentrations prepared and we thought that this rate would negatively effect the parasite development. Then, RPMI containing FCS was diluted in the medium and serial dilutions were prepared at concentrations between $50-800 \mu \mathrm{g} / \mathrm{ml}$. To the dilutions prepared, the promastigot suspension was added so that their final concentrations in the wells were $1 \times 10^{6}$ promastigot $/ \mathrm{ml}$ and then the medium was incubated for 24 and 48 hours in $26^{\circ} \mathrm{C}$. After the incubation, promastigotes were determined microscopically for morphology, mobility and live parasite density, and cell viability was determined by MTS method and $50 \%$ inhibitor concentrations $\left(\mathrm{IC}_{50}\right)$ were compared with control groups. Anti-leishmanial activity of propolis (50, 100, 200, 400 and $800 \mu \mathrm{g} / \mathrm{ml})$ and honey $(62.5,125,250$, 500 and $1000 \mathrm{mg} / \mathrm{ml}$ ) on promastigotes was evaluated in vitro. In microscopic examinations, pine honey showed anti-leishmanial activity starting from $62.5 \mathrm{mg} / \mathrm{ml}$, flower honey $250 \mathrm{mg} / \mathrm{ml}$, and chestnut honey $125 \mathrm{mg} / \mathrm{ml}$, and pine honey was more effective on promastigotes $(p<0.05)$, and propolis was effective from $100 \mu \mathrm{g} / \mathrm{ml}$ concentration. It has been determined that very low concentrations of propolis caused changes in the morphological structure of the parasites and were more effective than the other bee products. The prevention of cell proliferation and decreasing of the $\mathrm{IC}_{50}$ values according with the time of pine honey $\left(I C_{50}=109.28 \mathrm{mg} / \mathrm{ml}\right)$, flower honey $\left(I C_{50}=248.07 \mathrm{mg} / \mathrm{ml}\right)$, chestnut honey $\left(I_{50}=\right.$ $147.65 \mathrm{mg} / \mathrm{ml})$ and propolis $\left(\mathrm{IC}_{50}=82.98 \mu \mathrm{g} / \mathrm{ml}\right)$ applied on L.tropica promastigot cell culture was determined by MTS method. In this study, it was found that various concentrations of pine, flower, chestnut honey and propolis showed anti-leishmanial activity on L. tropica promastigotes. It has been observed that pine honey is more effective on promastigotes after 48 hours of incubation period, and propolis is more effective in both morphology and cell inhibition of the parasites even at very low concentrations. It is believed that these data can be used as an alternative treatment method against cutaneous leishmaniasis infections and further studies are required.

Keywords: Leishmania tropica; honey; propolis; anti-leishmanial effect

\section{Giriş}

Leishmania türleri, Kinetoplastea sınıfında ve Trypanosomatidae ailesinde yer alan intraselüler yaşayan doku parazitleri olup leyşmanyazis hastalığına neden olmaktadır. Leyşmanyazis dünyada sıtmadan sonra mortalite sıralamasında ikinci, tropikal paraziter hastalıklar içerisinde morbidite sıralamasında ise dördüncü sırada bulunmaktadır ${ }^{1}$. Leyşmanyazis ile dünya çapında 12 milyon insanın enfekte olduğu, tropikal ve subtropikal 98 ülke/bölgede 350 milyon insanın tehdit altında olduğu, ayrıca her yıl 1-2 milyon yeni olgunun eklendiği 
bildirilmiştir. Bu olguların 1.5 milyonu kutanöz leyşmanyazis (KL) iken 500.000'inin viseral leyşmanyazis $(\mathrm{VL})^{\prime}$ e ait olduğu tespit edilmiştir² . Leishmania spp. enfeksiyonlarında ilk tedavi seçeneği olarak beş değerli antimon bileşikleri uzun süreli ve günlük enjeksiyon şeklinde uygulanmaktadır. Leishmania spp.'ye karşı daha etkili ve daha az toksik bir ilaç henüz geliştirilememiş olmasına rağmen, Dünya Sağlık Örgütü (DSÖ) tarafından meglumin antimonat ve sodyum stiboglukonat önerilmektedir ${ }^{3}$. Tedavide kullanılan pentavalan antimon bileşiklerinin ve diğer tedavi edici ilaçların yan etkilerinin ve toksisitesinin olmasının, yüksek maliyete sahip olması ve bu ilaçlara karşı konakta bir direncin oluşmaşı aşı geliştirme çaış̧maları ve alternatif tedavi yöntemlerinin gerekliliğini gündeme getirmiştir ${ }^{4}$. Bu nedenle, insanlar doğal ürünleri bir ilaç olarak kullanmaya yönelmişlerdir. Kullanılan bu doğal ürünler arasında en çok tercih edilenler arı ürünleri olmaktadır. Arı ürünlerinin (bal, propolis, arı sütü, arı zehri ve bal mumu vb.) tıbbi amaçlı kullanımına apiterapi denilmektedir ${ }^{5}$. Apiterapik uygulamalar son yıllarda tıp alanında çok fazla gelişim göstermektedir. Arı ürünlerinin bir besin maddesi olması ve içerisinde yer alan fenolik karaktere sahip bileşiklerden dolayı birçok biyolojik aktif özelliği bulunmaktadır ${ }^{6}$.

Türkiye'de günümüze kadar parazitler üzerine, özellikle de Leishmania paraziti üzerine arı ürünlerinin (bal, propolis) birlikte kullanıldığı çalışmaların bulunmaması nedeniyle çalışmamız bu açıdan oldukça özgündür. Bu çalışmada bal ve propolisten oluşan arı ürünlerinin $\mathrm{KL}$ etkeni Leishmania tropica promastigotları üzerine in vitro antileyşmanyal etkinliğinin araştırılması amaçlanmıştır.

\section{GEREÇ ve YÖNTEM}

\section{Çalışmada Kullanılacak Besiyeri ve Çözeltilerin Hazırlanması}

Laboratuvarımızda bulunan "fetal calf serum (FCS)", penisilin (10.000 U/ml)streptomisin ( $10 \mathrm{mg} / \mathrm{ml}$ ) çözeltisi, L-glutamin çözeltisi ve RPMI-1640 besiyeri uygun koşullarda hazırlanarak kullanılıncaya kadar uygun koşullarda saklandı.

\section{L.tropica Promastigot Kültürü}

Kriyoprezervasyon uygulanarak sıvı azotta saklanan promastigotlar çıkartılarak sıcak su banyosunda hızlı bir şekilde çözdürüldü ve daha sonra RPMI-1640 besiyerinde kültüre alındı. Kültür flaskları, promastigotların gelişmesi ve çoğalması için $26^{\circ} \mathrm{C}^{\prime}$ de inkübasyona bırakıldı. Promastigotların gelişimi invert mikroskopta gün aşırı kontrol edildi. Besiyeri, promastigotların çoğalma yoğunluğuna göre pasaj yapılarak değiştirildi.

\section{Thoma Lamı ile Promastigot Sayımı}

L.tropica promastigotlarının sayımında thoma lamı kullanıldı. Flakslarda üretilen ve logaritmik faza giren L.tropica promastigot kültüründen 50 ml'lik konik tabanlı steril Falcon tüplerine alınarak 2000 devirde 10 dakika santrifüj edildi. Santrifüj edildikten sonra süpernatant atılıp çökelti, $5 \mathrm{ml}$ hücre besiyeri ile süspanse edildi. Süspanse L.tropica promastigot kültüründen $10 \mu \mathrm{l}, 40 \mu \mathrm{l}$ tripan mavisi ve $50 \mu \mathrm{l} \% 20^{\prime}$ lik formaldehit eklenerek 1 dakika bekletildi. Elde edilen bu süspansiyondan thoma lamının sayım kamarasına eklenerek lamel kapatıldı ve lamın her bir köşesinde bulunan toplam dört kare ve orta alandaki kare içeri- 
sinde bulunan promastigotlar sayıldı. Daha sonra parazit yoğunluğunun her bir kuyucukta $1 \times 10^{6}$ promastigot/ml parazit olacak şekilde sayılarak promastigot içeren süspansiyon hazırlandı.

\section{Bal ve Propolis Konsantrasyonlarının Hazırlanması}

Bal ve propolis, Zonguldak ili Arı Yetiştiricileri Birliği (ZAYBiR)'den temin edildi. Propolis kullanılacağı zamana kadar $-20^{\circ} \mathrm{C}$, bal ise oda ısısında saklandı. Propolis örnekleri, Özbilge ve arkadaşları ${ }^{7}$ tarafından verilen talimata göre etanol ekstraktı hazırlandı. Elde edilen ekstraktlar, $0.2 \mu \mathrm{m}$ por gözenekli filtreden geçirilerek 50-800 $\mu \mathrm{g} / \mathrm{ml}$ arasındaki konsantrasyonlarda seri dilüsyonları hazırlandı. Çalışmada çözücü olarak kullanılan etanol oranı, parazit gelişimini olumsuz etkileyeceğinden dolayı son konsantrasyonda \%0.3 olarak ayarlandı. Çalışmada kullanılan bal örnekleri ise RPMı besiyeri ile çözdürüldü, aynı besiyeri içerisinde sulandırıldı ve $0.2 \mu \mathrm{m}$ por gözenekli filtreden geçirilerek 1000-62.5 mg/ml arasındaki konsantrasyonlarda seri dilüsyonları hazırlandı. Hazırlanan propolis ve bal konsantrasyonları kullanıma kadar oda sıcaklığında ve karanlık bir ortamda saklandı.

\section{İn vitro Antileyşmanyal Aktivite}

Çalışmamızda, arı ürünlerinin L.tropica promastigotları üzerindeki antiparaziter etkinlikleri mikroplak dilüsyon yöntemi kullanılarak in vitro olarak test edildi. Düz tabanlı 96 kuyucuklu hücre kültür plağı yatay olarak kullanıldı ve 12 sıranın üçü ilaçsız parazit kontrol, üçü "blank" geri kalan kuyucuklar ise bal ve propolis konsantrasyonları için belirlendi. Her bir kuyucuğa \%10 inaktive edilmiş FCS, \%1 streptomisin-penisilin ve \%1 L-glutamin içeren RPMI-1640 besiyerinden $100 \mu \mathrm{l}$ dağıtıldı. Bal ve propolis konsantrasyonları için ayrılmış olan bölmeler, her birinin ilk kuyucuğuna istenilen bal, propolis konsantrasyonunun iki katı olacak şekilde standart besiyerine eklenerek $100 \mu \mathrm{l}$ hazırlandı. Bu çalışmada propolis için ilk doz $800 \mu \mathrm{g} / \mathrm{ml}$ bu nedenle $1600 \mu \mathrm{g} / \mathrm{ml}$ olacak şekilde bal örnekleri için ise ilk doz 1000 $\mathrm{mg} / \mathrm{ml}$ bu nedenle $2000 \mathrm{mg} / \mathrm{ml}$ olacak şekilde hazırlandı. Hazırladığımız bal ve propolisli besiyeri ilk kuyucuklara eklendi. Ardından çok kanallı pipet yardımıyla ilk kuyucuktan 100 $\mu$ l alınıp diğer kuyucuklara aktarım yapılarak seri dilüsyonlar hazırlandı (propolis için 800$50 \mu \mathrm{g} / \mathrm{ml}$, bal için 1000-62.5 mg/ml). Daha sonra sayımını yaptığımız ve hazırladığımız $1 \times 10^{6}$ promastigot/ml parazit süspansiyonundan $100 \mu$ l olacak şekilde tüm kuyucuklara eklendi (Blank kuyucuklarına parazit süspansiyonu eklenmedi). Hazırlanan 96 kuyucuklu hücre kültür plağının kapağı kapatılarak etrafı parafilmle kaplandı ve etüvde $26^{\circ} \mathrm{C}^{\prime}$ de 48 saat inkübe edildi. Inkübasyona bırakılan hücre kültür plakları 24 ve 48. saatlerde ışı ve invert mikroskopta incelenerek promastigotların morfolojisi, hareketlilikleri ve yoğunlukları kayıt altına alındı.

\section{MTS [3-(4,5-dimethylthiazol-2-yl)-5-(3-carboxymethoxyphenyl)-2-(4-)-2H] Yöntemi}

İnkübasyona bırakılan 96 kuyucuklu hücre kültür plakları 24 ve 48. saatlerde etüvden çıkartılarak her bir kuyucuktan $100 \mu \mathrm{l}$ alındı ve yeni bir 96 kuyucuklu düz tabanlı hücre kültür plağına aktarıldı. Ayrı bir yerde MTS yöntemi için, tetrazolyum bileşiği olan tek solüsyonlu MTS [CellTiter $96^{\circledR}$ Aqueous One Solution Reagent (MTS ayıracı)] kullanıldı. $-20^{\circ} \mathrm{C}^{\prime}$ de muhafaza edilen MTS solüsyonu, $37^{\circ} \mathrm{C}^{\prime}$ de su banyosunda 10 dakika inkübe edilerek çöz- 
dürüldü. Yeni 96 kuyucuklu düz tabanlı hücre kültür plağına aktarılan 100 ㅆ'lik hücre süspansiyonu üzerine $20 \mu \mathrm{l}$ MTS ayıracı eklendi. Ardından da 1-4 saat inkübasyona bırakıldı. İnkübasyon sonrası plaklar spektrofotometrede 490 nm'de okutuldu. Okuma sonrası elde edilen absorbans değerleri kaydedilerek canlılık hesaplaması yapıldı ve $\mathrm{IC}_{50}$ (maksimum inhibisyon konsantrasyonu) değerleri belirlendi.

\section{İstatistiksel Analiz}

Elde edilen veriler GraphPad Prism version 8.2.1 kullanılarak analiz edildi. IC $_{50}$ değerleri "dose-response-inhibition" kullanılarak hesaplandı. Veriler iki yönlü ANOVA ile istatistiksel olarak analiz edildi.

\section{BULGULAR}

Propolisin (50, 100, 200, 400 ve $800 \mu \mathrm{g} / \mathrm{ml})$ ve balların $(62.5,125,250,500$ ve 1000 $\mathrm{mg} / \mathrm{ml}$ ) beş farklı konsantrasyonu promastigotlar üzerine antileyşmanyal aktivitesi in vitro hücre kültür ortamında değerlendirilmiştir. Yirmi dört ve 48 saatlik inkübasyondan sonra parazit sayısı, hücre canlılığı (parazitlerin hareketliliği) ve hücre morfoloji açısından mikroskobik ve antileyşmanyal etkinliği açısından da MTS yöntemi ile değerlendirilmiştir.

Propolis örnekleri \%96 konsantrasyonda etanol içerisinde hazırlanmıştır. Kullanılan etanol oranının parazit üzerine inhibisyon etkisini değerlendirmek için kontrol deneyleri yapılmıştır. Seçilen alkol oranı (\%0.3) kontrol gruplarıyla karşılaştırıldığında parazit hücrelerinin büyümesini engellemediği vesitopatolojik değişiklikler oluşturmadığı gözlemlenmiş̧ir. Parazit hücreleri morfoloji açısından değerlendirildiğinde, propolis örneklerinin $100 \mu \mathrm{g} /$ ml'ye (100 $\mathrm{gg} / \mathrm{ml}$ dahil) kadar konsantrasyonlarda kullanıldığı deneylerde, parazit hücreleri üzerinde patolojik bir etki bulunmamıştır. Hücreler üzerinde herhangi bir nükleer ve sitoplazmik değişiklik saptanmamıştır. Ayrıca, 24 ve 48 saatlik inkübasyonun sonunda kontrol grubundan (parazit kontrol) alınan örneklerde parazit sayısında bir artış olduğu belirlenmiştir. Propolisin $200 \mu \mathrm{g} / \mathrm{ml}$ ve daha yüksek konsantrasyonlarında parazitlerin yuvarlaklaşması, çekirdeğin genişlemesi ve granülasyon gibi belirgin patolojik değişiklikleri indüklediği gözlemlenmiştir (Resim 1). 200, 400 ve $800 \mu \mathrm{g} / \mathrm{ml}$ konsantrasyonlarında propolis, L.tropica promastigotlarının hücresel büyümesini tamamen ortadan kaldırdığı tespit edilmiştir. Ayrıca inkübasyon süresinin artışıyla birlikte propolisin antileyşmanyal etkisinin de arttığı, hücre çoğalmasını engellediği hem mikroskobik olarak gözlemlenmiş hem de $\mathrm{IC}_{50}$ değerlerinin $\left(\mathrm{IC}_{50}=82.98 \mu \mathrm{g} / \mathrm{ml}\right)$ zamana bağlı olarak azaldığı MTS yöntemiyle tespit edilmiştir (Şekil 1).

Mikroskobik incelemelerde 24 saatlik inkübasyon sonunda çam balı $125 \mathrm{mg} / \mathrm{ml}$, çiçek balı $250 \mathrm{mg} / \mathrm{ml}$, kestane balı $125 \mathrm{mg} / \mathrm{ml}$ konsantrasyondan itibaren (Şekil 2), 48 saatlik inkübasyon sonunda ise çam balı $62.5 \mathrm{mg} / \mathrm{ml}$, çiçek balı $250 \mathrm{mg} / \mathrm{ml}$, kestane balı ise 125 $\mathrm{mg} / \mathrm{ml}$ konsantrasyondan itibaren (Şekil 3) canlı promastigot sayısında azalma, kamçı hareketinde yavaşlama, promastigot morfolojisinde değişmeler ve çok miktarda yuvarlak ve kümelenmiş parazitler gözlenmiştir (Resim 2). L.tropica promastigot hücre kültürü üzerine uygulanan çam balı $\left(\mathrm{IC}_{50}=109.28 \mathrm{mg} / \mathrm{ml}\right)$, çiçek balı $\left(\mathrm{IC}_{50}=248.07 \mathrm{mg} / \mathrm{ml}\right)$ ve kestane balı $\left(\mathrm{IC}_{50}=147.65 \mathrm{mg} / \mathrm{ml}\right)$ hücre çoğalmasını engellediği $(\mathrm{p}<0.05)$ ve $\mathrm{IC}_{50}$ değerlerinin zamana bağlı olarak azaldığı MTS yöntemiyle tespit edilmiştir. 


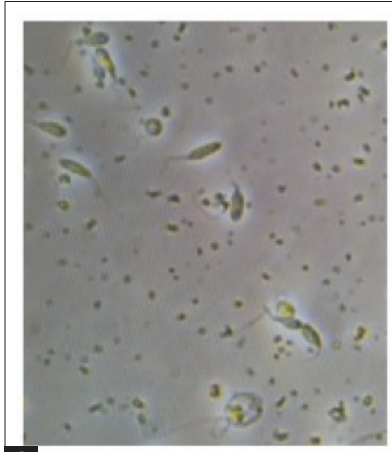

A

Resim 1. Propolisin promastigotlar üzerindeki morfolojik etkisi (A-B: Propolis + promastigot, C: Kontrol promastigot).
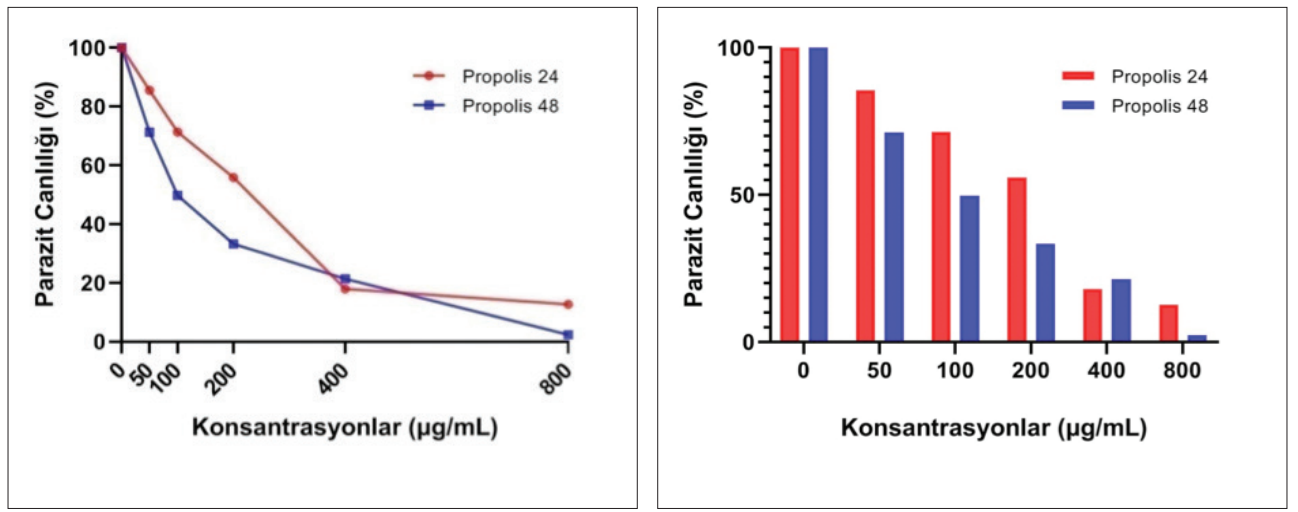

Şekil 1. Propolis örneklerinin 24-48. saat inkübasyon sonrası promastigotlar üzerindeki antileyşmanyal etkisi.
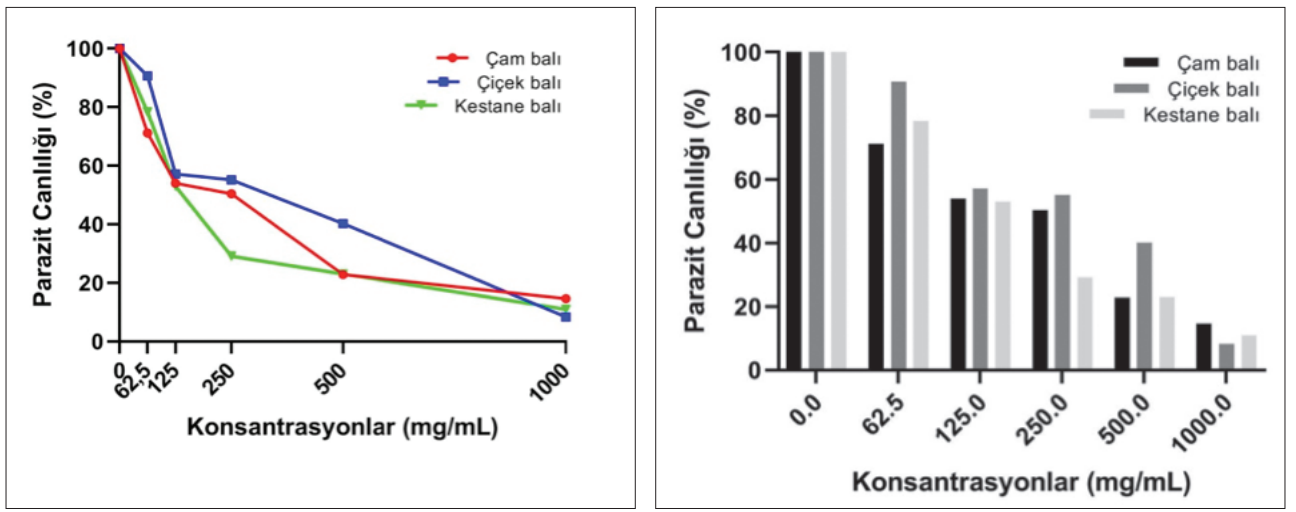

Şekil 2. Bal örneklerinin 24. saat inkübasyon sonrası promastigotlar üzerindeki antileyşmanyal etkisi. 

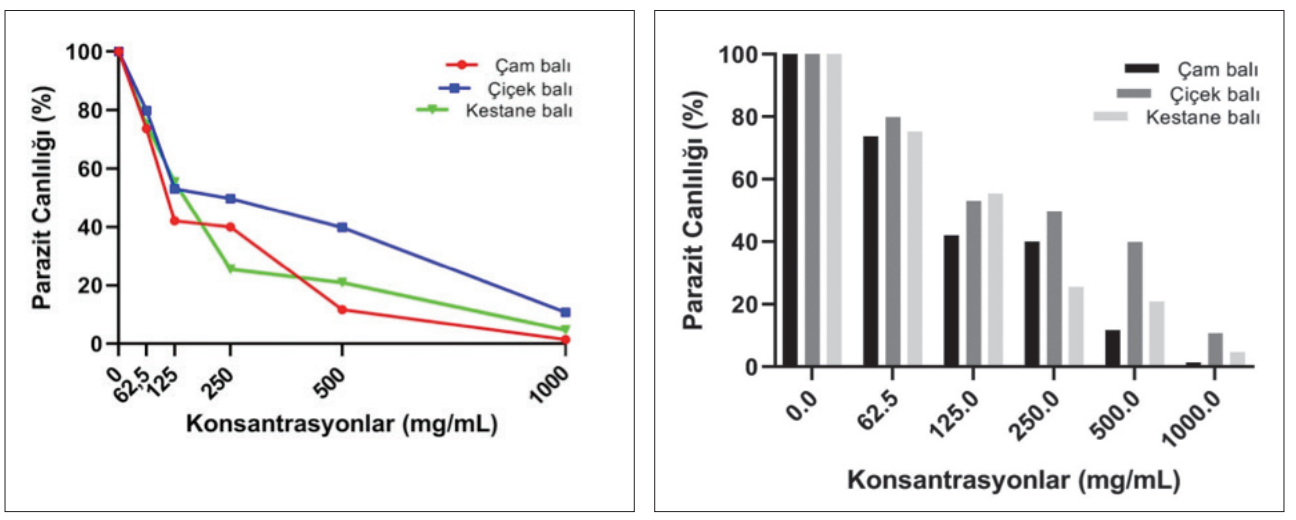

Şekil 3. Bal örneklerinin 48. saat inkübasyon sonrası promastigotlar üzerindeki antileyşmanyal etkisi.
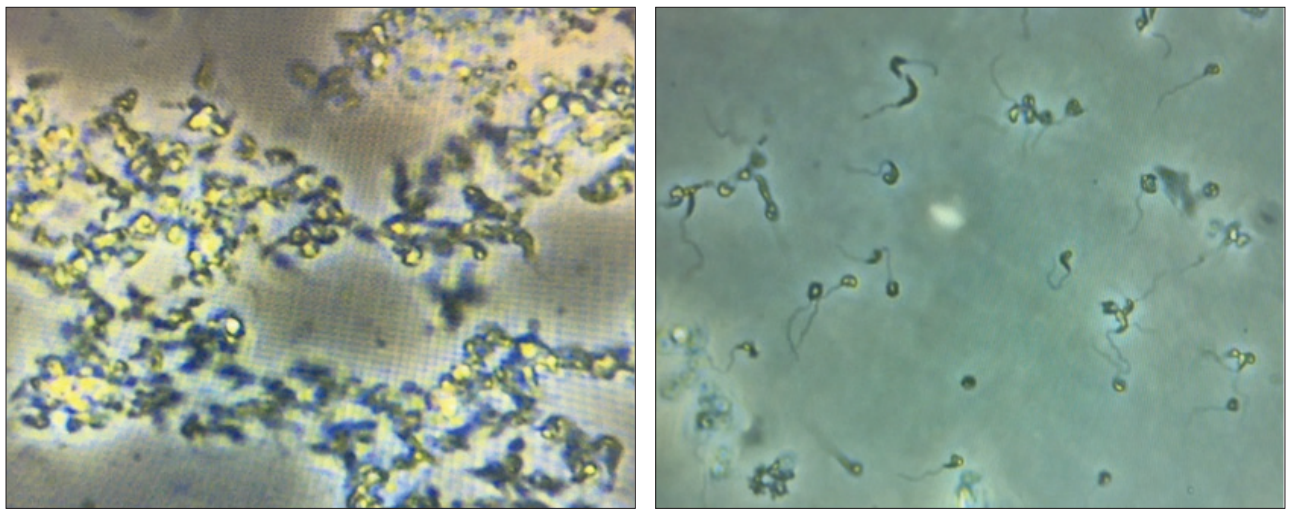

Resim 2. Çam balının promastigotlar üzerindeki morfolojik etkisi.

\section{TARTIŞMA}

Dünyanın ve ülkemizin önemli halk sağlığı problemlerinden birisi olan leyşmanyazis, dünyada sıtmadan sonra mortalite sıralamasında ikinci, tropikal paraziter hastalıklar içerisinde morbidite sıralamasında ise dördüncü sırada bulunmaktadır. Leyşmanyazisin genellikle ölüm ile sonuçlanan VL'den kendi kendine iyileşebilen $K L$ ve mukokutanöz leyşmanyazis (MKL) olmak üzere üç farklı klinik formu bulunmaktadır. $K L$, çoğunlukla deri ve deri mukozalarında skar bırakarak kendiliğinden iyileşebilen lezyon ya da lezyonlar ile kendini gösteren bir deri hastalığıdır. Bu lezyonlar kişilerde kendiliğinden veya tedavi ile iyileştikten sonra ömür boyu bir bağışıkıı bırakmaktadır. İyileşme bir yıl ya da daha fazla sürdüğü için özellikle endemik bölgelerde iyileşme süresini hızlandırmak için lezyonun tedavi edilmesi önerilmektedir ${ }^{8}$. Leishmania spp. enfeksiyonlarında ilk tedavi seçeneği olarak beş değerli antimon bileşikleri uzun süreli ve günlük enjeksiyon şeklinde uygulanmaktadır. Tedavide kullanılan pentavalan antimon bileşiklerinin ve diğer tedavi edici ilaçların, yan etkilerinin ve toksisitesinin olması, yüksek maliyete sahip olmaları ve 
bu ilaçlara karşı canlıda bir direncin oluşması gibi olumsuz özelliklerinden dolayı aşı geliştirme çalışmaları ve alternatif tedavi yöntemlerinin gerekliliğini gündeme getirmiştir ${ }^{4}$. Alternatif tedavi yöntemlerinden olan arı ürünlerinin (bal, propolis, arı sütü, arı zehri ve bal mumu vb.) tıbbi amaçlı kullanımına apiterapi denilmektedir ${ }^{5}$.

Arı ürünlerinin yüksek biyolojik aktif özelliğe sahip olduğunu gösteren birçok çalışma bulunmaktadır. Ancak parazitler üzerine, özellikle de Leishmania paraziti üzerine arı ürünlerinin (bal, propolis) bir arada olduğu çalışmaların bulunmaması çalışmamızı özgün kılmaktadır. Mevcut çalışmamızda çam balı, çiçek balı, kestane balı ve propolisten oluşan arı ürünlerinin $\mathrm{KL}$ etkeni L.tropica promastigotları üzerine in vitro antileyşmanyal etkinliği araştırılmıştır.

Balın hem doğal bir gıda maddesi ve önemli bir enerji kaynağı olması hem de içerisinde yer alan fenolik bileşikler ve diğer birçok madde sayesinde biyolojik aktif özellik kazandırması onu değerli yapmaktadır. Klinik ve laboratuvar çalışmaları da balın; mikroorganizmalar, mantarlar, protozoalar ve virüslere karşı antimikrobiyal özellik taşıdığını göstermektedir ${ }^{9}$. Leyşmanyazis lezyonlarının kronik olduğu ve enfeksiyonlara karşı duyarIı olduğu göz önüne alındığında çalışmamız, balın yukarıda belirtilen özelliklerinden yararlanılarak leyşmanyazis lezyonlarının tedavisi üzerine yapılacak daha sonraki çalışmalara zemin hazırlamak amacıyla yapılmıştır.

Nilforushzadeh ve arkadaşları 2007 yılında yaptıkları bir çalışmada ${ }^{10}$, KL'li 90 hasta seçerek iki grup oluşturmuştur. Birinci gruba meglumin antimonat ve tropik bal birlikte verilirken, ikinci gruba altı hafta boyunca sadece meglumin antimonat vermişlerdir. Sadece meglumin antimonat ile tedavi edilen grupta 32 (\%71.1) hasta tam iyileşme gösterirken, hem meglumin antimonat hem de bal ile tedavi edilen grupta 23 (\%51.1) hasta tam iyileşme göstermiş̧ir. Bu sonuç, istatistiksel olarak anlamlı bulunmuş ve araştırmacılar balın standardize edilmiş oranının sahip olduğu antibakteriyel etkinliğinden dolayı KL enfeksiyonlarının tedavisinde başarılı bir şekilde kullanılabileceğini bildirmişlerdir. Araştırmacılar aynı zamanda farklı bal çeşitlerinin antimikrobiyal özelliklerinin farklı olmasından ve bu nedenle tıbbi olarak bal ve meglumin antimonatın birlikte uygulanmasının balın etkinliğinin azalmasına neden olabileceğini bildirmişlerdir.

Bassam ve arkadaşları ${ }^{11}$ Leishmania parazitleri üzerine balın in vitro etkinliği üzerine ilk çalışmayı yapmış ve bu çalışma ile Leishmania major, L.tropica ve Leishmania infantum parazitleri üzerine bal dilüsyonlarının etkinliğini aynı konsantrasyonlardaki şeker dilüsyonları ile karşılaştırmışlardır. Bunun için hücre besiyeri içerisine $10^{4}, 10^{5}$ ve $10^{6}$ parazit/ $\mathrm{ml}$ olacak şekilde, bal ve şeker dilüsyonları da 1:1, 1:2, 1:4, 1:8, 1:16, 1:32 ve 1:64 g/ $\mathrm{ml}$ konsantrasyonlarında hazırlanıp eklenerek 24 saat inkübasyona bırakılmıştır. Bal ve şekerin tüm konsantrasyonları 24 saat sonunda $10^{4}$ ve $10^{5}$ parazit/ml parazit yüküne etki etmiş ancak $1 \times 10^{6}$ parazit $/ \mathrm{ml}$ parazit yüküne balın tüm konsantrasyonları etki etmesine rağmen, şekerin sadece 1:1 ve 1:2 dilüsyonları etki edebilmiştir. Çalışma ile bal ve şekerin antileyşmanyal etkinliğe sahip olduğu, fakat elde edilen sonuçlar ile balın şekerden daha 
üstün olduğunu ve balın düşük konsantrasyonlarının dahi parazit hareketini engelleme yeteneğinin olduğu sonucuna varmışlardır. Çalışmamızda, 1 × $10^{6}$ promastigot $/ \mathrm{ml}$ parazit üzerine 1000, 500, 250, 125 ve 62.5 mg/ml konsantrasyonlarındaki üç bal (çam, çiçek ve kestane) çeşidinin 24 ve 48 saatteki etkinliği araştırılmıştır. Yirmi dört saatlik inkübasyondan sonra çam balı $125 \mathrm{mg} / \mathrm{ml}$, çiçek balı $250 \mathrm{mg} / \mathrm{ml}$ ve kestane balında ise $125 \mathrm{mg} / \mathrm{ml}$ konsantrasyondan sonra parazitlerin morfolojisinde, hareketliliğinde ve yoğunluğunda değişmeler gözlemlenmiştir. Kırk sekizinci saatte ise bu durum daha düşük konsantrasyonlarda oluşmuştur. Zaman ilerledikçe balın parazit üzerine olan etkisinin doğru orantılı olarak değiştiği gözlemlenmiştir. Ayrıca üç çeşit balı karşılaştırdığımızda çam balının diğer iki bal çeşidine göre parazit üzerindeki etkisinin daha fazla olduğu görülmüş̧ür.

Doğal bir ürün olan propolis, toksik olmaması, geniş bir biyolojik aktiviteye sahip olması ve kolay elde edilebilir olması gibi özelliklerinden dolayı tedavi amacıyla kullanımı gün geçtikçe önem kazanmaktadır. Propolisin, Leishmania türleri üzerine antileyşmanyal aktivitesinin araştırıldığı birçok çalışma bulunmaktadır. Çeşitli çalışmalarda, propolisin antiprotozoal aktiviteleri incelenmiştir ${ }^{12,13}$. Bu çalışmalar, propolisin Leishmania türlerine karşı potansiyel antileyşmanyal aktiviteye sahip olma olasılığını desteklemektedir. Propolis, leyşmanyazise karşı potansiyel bir antiprotozoal ilaç olarak umut verici görünse de, geniş bir şekilde araştırılmamıştır. Leishmania'nın farklı türleri ve formları üzerine çeşitli çalışmalar bulunmakla birlikte, propolisin L.tropica üzerine etkinliğinin araştırıldığı sınırlı sayıda çalışma bulunmaktadır. Bu nedenle, bu çalışma propolis ekstraktının L.tropica promastigotları üzerine in vitro aktivitesini değerlendirmek için yapılmıştır.

Duran ve arkadaşları ${ }^{14}$ Adana propolis ekstraktının L.tropica'nın büyümesi üzerindeki in vitro etkinliğini araştırmışlardır. Bunun için parazit hücreleri, propolisin 25, 50, 100, 250, 500 ve $750 \mu \mathrm{g} / \mathrm{ml}$ konsantrasyonları ile muamele edilerek 24, 48 ve 72 saat inkübasyona bırakılmış ve süre sonunda hemasitometre ile hücre sayımı yapılmıştır. Bunun sonucunda propolisin $100 \mu \mathrm{g} / \mathrm{ml}^{\prime}$ ye kadar olan konsantrasyonlarının parazit hücrelerine karşı antileyşmanyal aktivite göstermediği ve bu konsantrasyonlarda parazitlerin morfolojisinde herhangi bir değişiklik olmadığı gözlenmiştir. Aynı zamanda Adana propolisinin 250, 500 ve $750 \mu \mathrm{g} / \mathrm{ml}$ konsantrasyonlarının L.tropica parazitlerinin çoğalmasını önemli ölçüde azalttığı, hatta bu durumun 48 saatlik inkübasyonda daha düşük konsantrasyonlarda gerçekleştiği bildirilmiştir. Çalışmamızda ise, 24 saatlik inkübasyonun ardından propolisin $200 \mu \mathrm{g} / \mathrm{ml}$ konsantrasyonda ve 48 saatlik inkübasyondan sonra ise $100 \mu \mathrm{g} /$ $\mathrm{ml}$ konsantrasyondan itibaren L.tropica promastigotları üzerine hem morfolojik hem de canlı sayısında azalma gibi önemli etkileri olduğu tespit edilmiştir. Duran ve arkadaş$\mid \operatorname{lar}^{14}$, propolis örneklerini dimetilsülfoksit (DMSO) içerisinde hazırlamış ve DMSO'nun çalışılan konsantrasyonlardaki parazitler üzerinde hiçbir etkisinin olmadığı bildirmiştir. Çalışmamızda ise, propolis için en iyi çözücülerden biri olan \%96'lık etil alkol kullanılmış ve böylece propolisin L.tropica promastigotları üzerindeki etkisini artırmada etkili olduğu sonucuna varılmıştır. Çünkü propolis, kloroform, eter, aseton gibi çözücülerde kısmen, 
alkolde oldukça fazla çözünürlük göstermekte, suda ise çok az ya da hiç çözünmemektedir. Çeşitli çalışmalarda etanol dışında metanol, glikol ve yağ gibi çözücülerde de çözündüğü bildirilmiştir. Eğer çözücü olarak etanol dışında bir madde kullanılırsa, propolisten elde edilecek birçok bileşenin izole edilemediği ve izole edilecek maddelerin farklılaştığı saptanmıştır ${ }^{15}$.

Machado ve arkadaşlarının 2007 yılında yaptıkları çalışmada ${ }^{16}$ Brezilya ve Bulgaristan orijinli propolis ekstraktlarının 2.8 ile $229.3 \mu \mathrm{g} / \mathrm{ml}$ konsantrasyonlarının, L.major, Leishmania braziliensis, Leishmania amazonensis ve Leishmania chagasi suşları üzerine inhibitör etkisinin olduğunu, propolisin ekstrakte edildiği yere göre etkinliğinin değiştiğini bu nedenle de Bulgaristan propolisinin düşük konsantrasyonlarının parazitler üzerinde daha etkin olduğu ayrıca propolisin bileşimindeki değişiklikten dolayı parazit üzerindeki etkisinin de değiştiğini bildirmişlerdir. Yine benzer bir şekilde, Ayres ve arkadaşları yaptıkları bir çalışmada ${ }^{12}$ Brezilya propolisinin, L.amazonensis promastigotları, hücre dışı amastigotlar ve enfekte peritoneal makrofajlar üzerindeki etkinliğini araştırmışlardır. Araştırmacılar etanolik ekstraktlarının makrofajlardaki L.amazonensis enfeksiyonunu azalttığını bildirmişlerdir. Çalışma ile farklı coğrafik bölgelerden toplanılan propolis örneklerinin biyolojik aktivitesinin, içerisinde yer alan tamamen farklı kimyasal bileşenlere sahip olmasından kaynaklandığı rapor edilmiştir. Çalışmamızda da benzer şekilde kullandığımız Karadeniz bölgesi orjinli propolisin, parazitin promastigot formuna karşı antileyşmanyal aktivite gösterdiği belirlenmiştir.

Sonuç olarak, bu çalışma ile KL etkeni L.tropica promastigotlarına karşı arı ürünlerinden çam, çiçek, kestane balı ve propolisin çeşitli konsantrasyonlarının L.tropica promastigotları üzerine antileyşmanyal etkinlik gösterdiği tespit edilmiştir. Elde edilen bu veriler doğrultusunda arı ürünlerinin KL enfeksiyonlarına karşı alternatif bir tedavi yöntemi olarak kullanılabileceği ve daha sonra yapılacak çalışmalar için iyi bir yol gösterici olacağı düşünülmektedir.

\section{ETIK KURUL ONAYI}

Bu çalışma için etik kurul onayı gerekmemektedir.

\section{ÇIKAR ÇATIŞMASI}

Yazarlar bu makale ile ilgili herhangi bir çıkar çatışması bildirmemişlerdir.

\section{KAYNAKLAR}

1. Chakravarty J, Sundar S. Current and emerging medications for the treatment of leishmaniasis. Expert Opin Pharmacother 2019; 20(10): 1251-65.

2. Passero LFD, Cruz LA, Santos-Gomes G, Rodrigues E, Laurenti MD, Lago JHG. Conventional versus natural alternative treatments for leishmaniasis: a review. Curr Top in Med Chem 2018; 18(15): 1275-86.

3. Machado PA, Carneiro MPD, Sousa-Batista AJ, Lopes FJP, Lima APCA, Chaves SP, et al. Leishmanicidal therapy targeted to parasite proteases. Life Sci 2019; 219: 163-81.

4. Ergüven S. Kan ve doku protozoonlarına karşı kullanılan yeni ilaçlar. Ankem Derg 2012; 26(Ek 2): 108-15. 
5. Cooper R. Honey as an effective antimicrobial treatment for chronic wounds: is there a place for it in modern medicine? Chronic Wound Care Man and Res 2014; 1: 15-22

6. Tezcan F, Kolaylı S, Ulusoy H, Erim FB. Evaluation of organic acid, saccharide composition and antioxidant properties of some authentic Turkish honeys. J Food Nutr Res 2011; 50(1): 33-40.

7. Özbilge H, Kaya E, Albayrak S, Silici S. Anti-leishmanial activities of ethanolic extract of Kayseri propolis. Afr J Microbiol Res 2010; 4(7): 556-60.

8. Berman J. Current treatment approaches to leishmaniasis. Curr Opin Infect Dis 2003; 16(5): 397-401.

9. Gürdal M, Kireçci S, Pirinçci N, Sakiz D, Karaman M. Greft ve flep tedavisinde doğal balın yara iyileşmesindeki etkisi. Turk J Urol 2003; 29(3): 245-9.

10. Nilforoushzadeh MA, Jaffary F, Moradi S, Derakhshan R, Haftbaradaran E. Effect of topical honey application along with intralesional injection of glucantime in the treatment of cutaneous leishmaniasis. BMC Complement Altern Med 2007; 7(1): 13.

11. Bassam Z, Zohra BI, Saada AA. The effects of honey on Leishmania parasites: an in vitro study. Trop Doct 1997; 27(Suppl 1): 36-8.

12. Ayres DC, Marcucci MC, Giorgio S. Effects of Brazilian propolis on Leishmania amazonensis. Mem Inst Oswaldo Cruz 2007; 102(2): 215-20.

13. Bankova V, De Castro SL, Marcucci MC. Propolis: recent advances in chemistry and plant origin. Apidologie 2000; 31(1): 3-15.

14. Duran G, Duran N, Çulha G, Özcan B, Öztas H, Özer B. In vitro anti-leishmanial activity of Adana propolis samples on Leishmania tropica: a preliminary study. Parasitol Res 2008; 102(6): 1217-25.

15. Burdock GA. Review of the biological properties and toxicity of bee propolis (propolis). Food Chem Toxicol 1998; 36(4): 347-63.

16. Machado GMC, Leon LL, Castro SL. Activity of Brazilian and Bulgarian propolis against different species of Leishmania. Mem Inst Oswaldo Cruz 2007; 102(1): 73-7. 